\title{
Australian Evidence on CEO Option Grants
}

\author{
Jean M Canil* \\ University of Adelaide, Australia \\ Bruce A. Rosser \\ University of Adelaide, Australia
}

We test the option incentive models of Hall and Murphy $(2000,2002)$ and Choe (2003). Hall and Murphy $(2000,2002)$ posit optimal grant size and exercise price contingent on the executive's levels of risk aversion and private diversification. Choe (2003) relates these choices to firm characteristics, principally the target risk level and financial leverage. A unique hand-collected data set of Australian grants is employed, wherein exercises prices and grant sizes are unconstrained by taxation and accounting practices. The Hall and Murphy $(2000,2002)$ model is found to explain observed exercise prices while neither model satisfactorily explains grant sizes. However, there is some evidence that CEO influence is associated with larger grants than posited by these optimal incentive models, but does not impact on exercise prices. (JEL: G39, G34)

Keywords: Executive, stock options, optimal, grant size, exercise price, governance

\section{Introduction}

The option incentive model of Hall and Murphy $(2000,2002)$ (hereafter, $\mathrm{HM}$ ) is an often-sited optimization model for option grants to executives. HM specify absolute pay-performance sensitivity as their incentive construct, implying that the optimum incentive is independent of the size of an option grant relative to the outstanding share capital of the host firm. This assumption contrasts with Jensen and Murphy (1990)

\footnotetext{
* Corresponding author: Business School, University of Adelaide, Australia, 5005; Phone: 618 83035534, Fax: 618 83034368. Email: jean.canil@adelaide.edu.au

(Multinational Finance Journal, 2012, vol. 16, no. 3/4, pp. 225-260)

(C) Multinational Finance Society, a nonprofit corporation. All rights reserved. DOI: $10.17578 / 16-3 / 4-3$
} 
who propose that option-based incentive is relative to the size of the host firm's outstanding share capital. HM endogenize the dual choices of grant size and exercise price in a setting that recognizes the risk aversion and private diversification of the CEO. In another vein, Choe (2003) (hereafter, $\mathrm{CH}$ ) prescribes the same choices but in relation to the target risk desired by shareholders and current financial leverage without appeal to CEO attributes. The models are related in that both assume constant executive productivity along with zero agency costs of equity. Despite their relative importance, no direct tests of either model have been reported. In contrast, option optimization models that endogenize executive productivity (e.g., Baker and Hall, 2004) and simultaneous grants of restricted stock (e.g., Kadan and Swinkels, 2008; Dittman and Maug, 2007) have been in-sample tested. Thus, the first objective is to perform direct tests of $\mathrm{HM}$ and $\mathrm{CH}$.

A behavioral perspective is suggested by Bertrand and Mullainathan (2000), Bebchuk and Fried (2003) and Bebchuk, Grinstein and Peyer (2010) and others who provide compelling evidence that CEOs influence the timing of their option grants. Hence, it is also likely that influential CEOs can impact the terms and conditions of their option grants including the grant size and the exercise price. Since option optimization models typically employ a principal-agent setting the prospect of CEOs influencing grants is already accommodated. However, the possibility remains that corporate governance characteristics impact on the internal arguments of either model. Weak corporate governance suggests CEO influence. In turn, weak governance may be reflected in CEOs being more risk-averse or setting lower target risk than preferred by shareholders. Thus, the extent to which the HM and $\mathrm{CH}$ models are vulnerable to the presence of $\mathrm{CEO}$ influence is also tested, constituting the second objective.

The contribution of the present paper is reflected in the twin objectives, realization of which requires that exercise prices and grant sizes are free to vary and are unconstrained by disclosure, taxation and corporate restrictions. The common U.S. practice of awarding at-the-money (ATM) grants to corporate is therefore an obstacle. Hall and Murphy (2002) report that 94 per cent of options granted to CEOs of S\&P 500 companies in 1998 were ATM grants. Narayanan and Seyhun (2006) suggest two reasons why in-the-money (ITM) grants are uncommon in the U.S. First, FASB rules require ITM options (as distinct from option value) to be expensed. Second, ITM options are not deductible under the Internal Revenue Code if an executive's total 
non-performance-based compensation exceeds $\$ 1$ million a year. In contrast, during the sample period Australian exercise prices did not cluster strongly around the grant stock price because (i) expensing was not required for accounting purposes and (ii) income tax was (and still is) not levied on the recipient until the options were exercised. At the same time, shareholders activism was in its infancy and large grants to CEOs were rarely questioned. Using (to the best of our knowledge) a unique dataset of Australian grants where both exercise prices and grant sizes are allowed to vary, ${ }^{1}$ the $\mathrm{HM}$ and $\mathrm{CH}$ models are tested together with documenting the extent to which governance factors impinge on optimal option-based incentivization.

The principal finding is that he HM model satisfactorily explains exercise prices with reference to CEO risk aversion and private diversification but fails to explain grant sizes. The $\mathrm{CH}$ model does not explain exercise prices and offers a minimal understanding of grant sizes. Thus, neither $\mathrm{HM}$ nor $\mathrm{CH}$ satisfactorily explain grant sizes. A further finding is that CEO influence, as represented by a set of governance variables, is instrumental in explaining grant sizes once the direct impact on exercise prices is taken into account.

The remainder of the paper is organized as follows. Section II provides background to the Australian institutional setting for executive option plans. Section III reviews present understanding and evidence on the relations between compensation structure, grant moneyness, incentive and CEO performance. The measures used are described in section IV, which is followed in section $\mathrm{V}$ by the data, sample and methodology. The analysis is discussed in section VI, with conclusions presented in section VII.

\section{Background}

Executive stock option plans in Australia and the U.S. typically set the parameters under which subsequent grants are made and require shareholder approval. Plans usually specify the term, the vesting period, a hurdle price, other restrictions (e.g. staging exercise of ITM options), a schedule (if any) and often capping the number of options that can be

1. Dittmann and $\mathrm{Yu}$ (2010) make the same observation. 
granted over a fixed interval (e.g. a moving five- year total). ${ }^{2}$ However, even in the presence of temporal capping compensation committees still have considerable latitude in allocating grants from one year to another. Typically, the exercise price is determined in relation to a formula with some imbedding discounts or premiums, while some companies grant full discretion to the compensation committee. ${ }^{3}$ The size of a grant is usually less restricted and is sometimes capped at a given number on a rolling basis for a fixed interval. ${ }^{4}$ The timing of a grant is least restricted, with most plans granting shareholders the right to award as they see fit, but lack of a timing constraint can also be exploited by CEOs. In other words, compensation committees are able to use their discretion in making grants under the auspice of a given plan. A risk facing shareholders is that a self-interested CEO exerts influence on the deliberations of the compensation committee to secure grant terms favoring the CEO at shareholder expense.

In Australia, as in the United States, shareholders must approve CEO stock option plans put to them by company compensation committees, usually in the Annual General Meeting. The procedure for granting options comprises the following steps: (i) notice of a shareholder meeting to approve a grant is issued, (ii) if approved, execution of the grant is usually left to the discretion of the compensation committee and notified to the ASX in the Notice of Directors' Interests (pursuant to the then Corporations Act, Section 235). For the duration of the sample period, the notice was to be lodged within 14 days of the grant (Section 205G). ${ }^{5}$ Any issue of securities (including options) to a director of a

2. Australian executive stock option plans are partially surveyed in Rosser and Canil (2004) and Taylor and Coulton (2002), while U.S. executive stock option plans are partially surveyed in Hall (1999).

3. For example, North Limited, ICI Australia Limited and Ashton Mining Limited prescribe an exercise price being the average of the stock price for the prior 5 trading days, with some companies (e.g., Energy Equity Limited) adding a requirement for a premium to market and others (e.g., Orbital Engine Limited) adding a requirement for a discount. Amcor Limited and BRL Hardy Limited, for example, grant full discretion to their compensation committees.

4. One plan states that "the total number of unissued shares... shall not exceed 7.5 per cent of the company's total number of shares on issue from time to time" (F. H. Faulding \& Co Limited Employee Share Option Plan: Plan Rules as of 18 February, 1988).

5. More recently, disclosure rules in both the U.S. and Australia have been tightened. In the U.S., in line with Section 403 of the Sarbanes-Oxley Act which became effective in 2002, the SEC amended the disclosure rules for beneficiary ownership reports to be filed 
company must be approved by shareholders of the company prior to the issue (ASX Listing Rule 10.11). The grant announcement date is the date on which the ASX publishes the notification by the granting company, and was used to determine grant discounts and premiums. Exercise details were obtained from the ASX Additions to the Official List.

As in the U.S., compensation committees in Australia typically have discretion as to the frequency, the size and timing of grants along with determination of the exercise price. ${ }^{6}$ The quality of Australian disclosure is on a par with the U.K. data of Conyon and Sadler (2001). ${ }^{7}$ Spreads in exercise prices and exercise dates were intended to increase the probability that at least one of the grants would be exercised. Otherwise, such grants have the same properties as single grants. Compensation specialists in Australia consider that nearly all stock option grants made during this period were add-ons and not substitutes. Add-on grants are also common in the U.S., as indicated by Hall and Murphy (2002) and Baranchuk (2006) who notes simultaneous growth in option grants along with CEO salaries, bonuses and other benefits. Irregular grants are all grants that are not regular, which comprise first grants to a newly-appointed CEO and those made within four weeks of the anniversary of a prior grant to the same CEO.

\section{Option incentivization}

Coles, Daniel and Naveen (2006) find that risk-averse and under-diversified managers are encouraged to avoid more risky (and potentially valuable) new investment when their compensation has high pay-performance sensitivity, as measured by delta. In contrast, when option compensation has high sensitivity to stock volatility (as measured

under Section 16(a) to be reported within two business days of receiving notification of the grant. In Australia, ASX Listing Rule 3.19A introduced in 2001 requires any change in directors' interests to be notified within 5 business days of the change.

6. Comparatively few plans specify grant frequency schedules; most leave this to the discretion of the compensation committee. Scheduled versus unscheduled grants in the U.S. are examined by Collins, Gong and Li (2005).

7. In the U.K., Urgent Issue Task Force (UITF) Abstract 10 of the Accounting Standards Board forms the basis of executive stock options disclosure, and is similar to the Australian disclosure rules as embodied in s.205G of the Corporations Act. 
by vega), managers have an incentive to accept more risks along with higher leverage. Two studies examine the relation between pay-performance sensitivity and the propensity for risk-taking. First, Guay (1999) finds that stock options significantly increase the sensitivity of CEO wealth to equity risk, and interprets the result as consistent with managers receiving incentives to invest in risk-increasing projects, particularly when the potential loss from underinvestment is greatest. The positive relation between stock volatility and pay-performance sensitivity (grant size multiplied by the option delta) increases the convexity of the relation between manager's wealth and the stock price. Second, Aggarwal and Samwick (1999) find that pay-performance sensitivity necessarily decreases in the variance of firm performance, i.e., more volatile stocks require lower executive pay-performance sensitivity to maintain a given incentive. While evidence of a positive association between pay-performance sensitivity and firm performance has been already been documented (for example, Jensen and Murphy, 1990; Hall and Liebman, 1998; Guay, 1999 and Core and Guay, 2005) no evidence has been reported on the determinants of exercise prices and grant size.

For a given option delta HM argue that pay-performance sensitivity is optimized when the exercise price and grant size are jointly set in relation to the executive's levels of absolute risk aversion and private diversification. Highly risk-averse executives are optimally incentivized with deep ITM grants (restricted stock at the limit) of small size because deep ITM grants are more costly to shareholders. Conversely, executives with low risk aversion are optimally incentivized by large OTM grants. The level of private diversification has an opposite impact to aversion. For example, poorly-diversified executives can ill afford increased exposure to idiosyncratic risk so are optimally satisfied by small ITM grants, whereas well-diversified executives are satisfied by large OTM grants. Assuming add-on grants, for a given grant size increasing risk aversion and lower private diversification require higher incentive (delta) via a lower exercise price. For example, for risk aversion of three and 50 per cent private investment in company stock a grant discount of approximately 35 per cent to market is implied. Alternatively, for a given grant size, decreasing risk aversion and/or higher private diversification require lower incentive via a higher exercise price. For example, for a risk aversion value of 2 and 50 per cent private investment in company stock a grant premium of approximately 20 per cent is implied. Since their model has shallow 
convexity of pay-performance sensitivity in exercise price/stock price, they recommend ATM or near-ATM grants. ${ }^{8}$

The preceding arguments generate the following propositions on the internal arguments of HM:

\#1 Grant size (in absolute terms) is increasing in the exercise price while delta is expected decreasing in the exercise price. Since variation in grant size is much larger than variation in delta, the former relation is expected to dominate. Thus, pay-performance sensitivity $(n \Delta)$ is expected to vary positively with the exercise price.

\#2 Pay-performance sensitivity is decreasing in (absolute) risk aversion because a higher delta implies a lower exercise price which $\mathrm{HM}$ advocate for more risk-averse CEOs to increase the incentive for risk-taking, reinforced by a positive relation between grant size and the exercise price.

\#3 Pay-performance sensitivity is increasing in private diversification because a higher delta implies a lower exercise price which $\mathrm{HM}$ advocate for less privately-diversified CEOs, reinforced by a positive relation between grant size and the exercise price.

In an alternative approach, $\mathrm{CH}$ argues that pay-performance sensitivity implied by grant size and exercise price choices is adjusted for (exogenous) stock price volatility and leverage to maintain the incentive level preferred by shareholders. $\mathrm{CH}$ distinguishes change in stock volatility induced by acceptance of new investments from change induced by changed financial risk when debt financing is used. When new investment is riskier than existing assets, for a given grant size the exercise price is increased to maintain a desired pay-performance sensitivity, while for a given exercise price grant size is reduced. On the other hand, if leverage is increased to finance new investment, the higher financial risk results in a larger grant for a given exercise price,

8. Alternatively, when stock option grants substitute for some component of existing compensation, HM show that the optimum policy shifts to stock options with a zero exercise price, or restricted shares, which increase executive incentive relative to options. Thus, ATM substitute grants are less efficient than restricted shares and also inferior to ATM add-on grants. Substitute grants also do not lower incentive because CEOs do not rationally exchange cash benefits for lesser option value. 
while for a given grant size the exercise price is reduced. The $\mathrm{CH}$ model predicts that increased stock volatility induces smaller grants but does not impact on the exercise price, while increased leverage induces a lower exercise price but does not impact on grant size.

$\mathrm{CH}$ generates a complementary set of compensation predictions with respect to financial characteristics without recourse to risk aversion and private diversification arguments. He argues that pay-performance sensitivity implied by grant size and exercise price choices is adjusted for exogenous changes in stock price volatility and financial leverage to maintain the optimum pre-existing incentive. Changes in leverage and stock volatility induced by acceptance of the proposed new investment cause the exercise price and grant size to adjust so as to arrive at the optimal pay-performance sensitivity necessary to capture new investment opportunities. ${ }^{9}$ Two scenarios are identified. The first draws upon the positive relation between stock volatility and option value. An increase in stock volatility caused by acceptance of riskier investments (i.e., target risk) increases option value, so for a given exercise price grant size is reduced to maintain optimal pay-performance sensitivity. ${ }^{10}$ Alternatively, when grant size is given, a higher exercise price is necessary to maintain optimal pay-performance sensitivity when target risk is increased. The second scenario introduces the two-edged impact of leverage on option value. Higher leverage (e.g., from financing the proposed investment with debt) reduces the residual claim of equity and increases financial risk, so for a given exercise price grant size is increased. Alternatively, for a given grant size the exercise price is reduced. Hence, ITM (OTM) grants are expected more likely when the target risk level is lower (higher) and debt is higher (lower).

For an all-equity firm, the argument is that a fall in target risk can be compensated by either a lower exercise price (conditional on grant size) which increases delta, or by a larger option grant (conditional on the exercise price) such that pay-performance sensitivity is restored.

9. The argument is consistent with Guay (1999) who finds that stock options significantly increase the sensitivity of CEO wealth to equity risk, where the sensitivity is positively related to firms' investment opportunities.

10. Carpenter (2000) constructs a model that optimizes the portfolio choice problem of a risk-averse manager compensated with call options that she cannot hedge. One of the predictions is that giving the managers more options causes her to reduce the volatility of the marginal investment, which is opposite to $\mathrm{CH}$. Thus, a positive relation between grant size and stock volatility (proxying for future stock volatility) supports $\mathrm{CH}$ whereas a negative relation supports Carpenter. 
However, to generate the pay-performance sensitivity necessary to capture given investment opportunities, adjusting the exercise price is ruled out in favor of operating on the grant size. An increase in stock volatility (consequent on accepting a new project) increases delta and hence pay-performance sensitivity, without intervention. However, reducing the exercise price (for a given grant size) is counter-productive because a lower exercise price reinforces the higher volatility effect. ${ }^{11}$

Hence, the only alternative for shareholders is to increase grant size. Debt impacts on both the exercise price and financial risk. Since equity-related compensation ranks after debt, the effective exercise price is increased by the face value of new debt that requires an increase in pay-performance sensitivity. On the other hand, higher financial risk requires a downward adjustment to pay-performance sensitivity via either a higher exercise price or a smaller grant. The dual impacts of leverage are therefore offsetting with respect to pay-performance sensitivity. Since the exercise price effect dominates the financial risk effect, a lower exercise price is expected because increasing grant size at the higher exercise price (due to higher leverage) is less effective in increasing pay-performance sensitivity. Hence, for a given pay-performance sensitivity, $\mathrm{CH}$ posits an inverse relation between the option exercise price and leverage.

Paraphrasing these arguments in relation to pay-performance sensitivity leads to the following propositions on the behavior of pay-performance sensitivity with respect to target risk and financial leverage, as follows:

\#4 For a fixed exercise price, grant size is decreasing in target risk because the value of options increases with target risk allowing a smaller grant to maintain the same pay-performance sensitivity.

\#5 For a fixed exercise price, grant size increases in financial leverage because the value of options decreases with financial leverage requiring a larger grant to maintain the same pay-performance sensitivity.

11. Carpenter (2000) has a related proposition that deep OTM grants possibly provide incentive for excessive risk-taking to increase the probability of exercise. However, Carpenter's approach differs from that of $\mathrm{CH}$ in at least two respects: first, grant size is not optimized to maintain a given pay-performance sensitivity, and second, Carpenter (contrary to $\mathrm{CH}$ ) models a change in the exercise price as impacting on stock volatility. 
\#6 For a given number of options granted, the exercise price is increasing in target risk because the value of options increases with target risk thereby requiring a higher exercise price to maintain the same pay-performance sensitivity.

\#7 For a given number of options granted, the exercise price is decreasing in financial leverage because the value of options decreases with financial leverage thereby allowing a lower exercise price to maintain the same pay-performance sensitivity.

\section{Measures}

\section{A. Pay-performance sensitivity}

HM measure pay-performance sensitivity in absolute terms by $n \Delta$ where $\Delta$ is measured by $N\left(d_{1}\right)$ which is dividend-adjusted. ${ }^{12}$ In so doing, HM eschew the relative pay-performance sensitivity measure of Jensen and Murphy (1990) which additionally is divided by the number of common stock outstanding. $\mathrm{CH}$ employs $n(X / P)$, where $X$ is the exercise price and $P$ is the stock price at grant. Both measures imply that $\mathrm{CEO}$ incentive is independent of firm size.

\section{B. Risk aversion and private diversification}

Although the level of CEO risk aversion and the degree of private diversification are not directly observed, we have confidence in our proxies that are derived from direct measures of inside wealth and private wealth disclosures, respectively. Following Becker (2006), absolute risk aversion $(\rho)$ is proxied by $\ln (o w)$ where ow is outside wealth. This measure implies a constant relative risk aversion of unity. Since outside wealth is not directly observable (though in cases of high-profile CEOs this can be estimated approximately) a proxy that is independent of inside wealth $(i w)$, being the value of stock and exercisable options (multiplied by delta) held, is employed. Given that the Australian wage structure is skill-differentiated and marginal tax

12. Meulbroek (2001) and others show that executives value their option grants at less than the market or Black-Scholes value. Following Hall and Murphy (2002, p. 25), we assume that executives' valuation is proportional to market value over a wide range of grant discounts/premiums. 
rates are lower than in Europe, executives are able to accumulate significant wealth from salary alone. Since the value of inherited wealth is not directly observable, it is assumed that outside wealth $(o w)$ is sourced from the accumulated portion of salary that is re-invested irrespective of the degree of private diversification that the CEO prefers. $o w$ is proxied by $\alpha($ Salary $\times$ Working life $)$, where $\alpha$ is the annual salary reinvestment factor, Salary is the salary at the beginning of the grant year, Working life is the CEO's age minus 28 years (being the earliest age at which a sampled CEO was appointed minus 1). The salary reinvestment factor is assumed constant across the sample, i.e., across salary growth rates. $\alpha=0.5$ is the value found to deliver estimates of outside wealth $(\mathrm{ow})$ that accord with knowledge of the approximate total wealth of selected high-profile CEOs and of $\rho$ that accord with observed values elsewhere (e.g., Dittmann and Maug (2007). The intuition is that the exertion value of a given CEO is embodied in her current salary which reflects a CEO's present worth having accumulated over her working life and which extends linearly to other board appointments.

The level of private diversification is proxied by a count of the public disclosures of separate private assets or investments, typically including equity investments, property, business ownership and pension entitlements (or superannuation in Australia). In doing so, it is tacitly assumed that the asset classes are equally-weighted. Private assets or investments are disclosed in a range of public sources, including contemporary editions of The Australian Financial Review, Business Review Weekly, Who's Who in Business in Australia together with ASX filings, company annual reports and company announcements including biographical details typically published on appointment. An assumption is that pension benefits and outside investments are of similar magnitude which is reasonable because small investments are unlikely to warrant disclosure in the public domain. Both risk aversion and private diversification are later evaluated on expected relations with other firm and CEO variables.

\section{Target risk}

Target risk is obtained from Baker and Hall (2004) using a two-stage procedure. The first step is to solve for the marginal productivity of CEO effort $(\gamma)$ using pre-grant CEO equity ownership $\left(b^{*}\right)$ which is assumed already optimized from $b^{*}=\frac{\gamma^{2}}{\gamma^{2}+2 \rho \sigma^{2}}$, where $\sigma$ is measured 
by the annualized standard deviation of pre-grant monthly stock returns over a minimum of 36 months prior to grant and $\gamma$ is $\sqrt{\frac{2 b^{*} \rho \sigma^{2}}{1-b^{*}}}$. Second, since $\mathrm{CH}$ assumes constant $\gamma$, which is solved recursively for $\sigma$ substituting post-for pre-grant equity ownership weighting the granted options by the probability of exercise, $N\left(d_{2}\right)$ and assuming $\gamma$ has not changed from the pre-grant level. Consistent with the increased risk-taking motive for granting options, the post-grant $\sigma$ always exceeds the pre-grant $\sigma$, so target risk is expressed as $\frac{\text { post }- \text { grant } \sigma}{\text { pre }- \text { grant } \sigma}$. Other things equal, this procedure results in a target risk that increases with grant size, which is intuitively appealing.

\section{CEO influence}

In the absence of a corporate governance index for Australian firms, CEO influence is proxied by a composite of several variables, comprising Board size, Proportion of outside directors, Tenure, CEO entrenchment, Founder, Number of public appointments and Private boards.. Each variable is explained in table 1.

\section{E. Moneyness}

An OTM grant is defined to occur when the stock price at grant exceeds the exercise price by 2 or more per cent; likewise, an ITM grant occurs when the stock price falls below the exercise price by the same percentage. Notional ITM grants/OTM grants below 2 per cent are therefore classified as ATM awards. The resulting 4 per cent spread is considered wide enough to classify virtually all ATM grants correctly, i.e., Type 1 error is believed negligible. ${ }^{13}$ The likelihood of Type 2 error (misclassifying non-ATM grants) is therefore likely higher than Type 1 error. Thus, grants classified as ITM or OTM are almost certainly not due to noise in stock prices. Further, the risk of classifying some non-ATM grants as ATM grants is not a problem for the Hall and Murphy (2002) predictions of add-on optimality because their model

13. The analysis was also performed with a five per cent cut-off, i.e., with a ten per cent spread. Although not reported, the results were not significantly different. 
TABLE 1. Explanation of governance variables

\begin{tabular}{|c|c|c|c|}
\hline Variable & Measure & $\begin{array}{l}\text { Expected } \\
\text { sign for } \\
\text { CEO } \\
\text { influence }\end{array}$ & Explanation \\
\hline Board size & $\begin{array}{l}\text { The number of all } \\
\text { directors sitting on the } \\
\text { board of the parent } \\
\text { company }\end{array}$ & positive & $\begin{array}{l}\text { Yermack (1995): Larger } \\
\text { boards suggest poorer } \\
\text { corporate governance and } \\
\text { hence CEO influence }\end{array}$ \\
\hline $\begin{array}{l}\text { Proportion of } \\
\text { outside } \\
\text { directors }\end{array}$ & $\begin{array}{l}\text { The number of directors } \\
\text { not employed within the } \\
\text { corporate group divided } \\
\text { by the number of } \\
\text { directors on the board }\end{array}$ & negative & $\begin{array}{l}\text { Weisbach (1988): A higher } \\
\text { proportion of outside directors } \\
\text { (i.e., not employed within the } \\
\text { corporate group) strengthens } \\
\text { board independence which } \\
\text { lowers the probability of CEO } \\
\text { entrenchment }\end{array}$ \\
\hline Tenure & $\begin{array}{l}\text { Tenure is the number of } \\
\text { years since appointment } \\
\text { as CEO }\end{array}$ & positive & $\begin{array}{l}\text { Yermack (1995): CEOs with } \\
\text { longer tenure are more likely } \\
\text { entrenched }\end{array}$ \\
\hline $\begin{array}{l}\text { CEO } \\
\text { entrenchment } \\
(=1)\end{array}$ & $\begin{array}{l}\text { CEO entrenchment }(=1) \\
\text { when pre-grant equity } \\
\text { ownership is between } 5 \\
\text { and } 25 \text { per cent (Morck, } \\
\text { Shleifer and Vishny, } \\
\text { 1988) }\end{array}$ & positive & $\begin{array}{l}\text { Jensen and Meckling (1976): } \\
\text { Entrenched CEOs do not act } \\
\text { in shareholders' interests }\end{array}$ \\
\hline $\begin{array}{l}\text { Public } \\
\text { appointments }\end{array}$ & $\begin{array}{l}\text { The number of } \\
\text { governmental, community } \\
\text { and professional } \\
\text { appointments held }\end{array}$ & negative & $\begin{array}{l}\text { Proxies reputation of CEO: } \\
\text { More reputable CEOs suffer } \\
\text { reputation loss if firm } \\
\text { governance is poor and hence } \\
\text { are less likely to exert } \\
\text { influence (Jian and Lee, 2011) }\end{array}$ \\
\hline $\begin{array}{l}\text { Private } \\
\text { boards }\end{array}$ & $\begin{array}{l}\text { The number of private } \\
\text { boards on which CEO sits }\end{array}$ & negative & $\begin{array}{l}\text { Higher number of board } \\
\text { appointments signal higher } \\
\text { level of competency }\end{array}$ \\
\hline Founder & $\begin{array}{l}\text { Equals } 1 \text { if CEO is the } \\
\text { founder }\end{array}$ & negative & $\begin{array}{l}\text { A founder has influence which } \\
\text { is likely benign given the } \\
\text { founder is still CEO }\end{array}$ \\
\hline
\end{tabular}


does not present corner solutions. Rather, their model permits some variation in moneyness around exact ATM without materially affecting their predictions. If their prediction were to hold only for exact ATM grants, such evidence would not be supportive of their position.

\section{Data, sample and methodology}

The sample period is 1987-2002. This period was chosen to ensure that ITM and OTM grants were voluntary choices and not influenced by subsequent controversy concerning the accounting treatment of non-ATM grants. In Australia, the expensing debate was unresolved until July, 2004 when AASB 2 became effective. The accounting debate in Australia can be traced back to the release of the International Accounting Standards Board (IASB) in mid-2002 which stated that all share-based payments should be recognized in the financial statements of issuing companies. ${ }^{14}$ Hence, to avoid any anticipation of expensing requirements, cases were not selected after 2002. Information of option grants on Australian executive option grants are obtained primarily from the set of option plans hand-collected by Rosser and Canil (2004) in their study of plan characteristics and grant moneyness and augmented by further plans that became available after that study was completed. These sources gave a pool of 97 plans covering 560 grants for the period 1987-2002. Filters were then applied (i) to remove cases with inadequate disclosures including those for which CEO private wealth cannot be ascertained and (ii) to exclude grants made within three days of other major announcements (such as earnings releases) to increase the likelihood that a given premium or discount was intentional. Application of these filters yielded a final sample of 202 stock option grants made by 70 companies to 88 CEOs. ${ }^{15}$ The final sample is spread across a number of industries based on the then-applicable Global Industry Classification System (GICS) with Resources/Energy (25.2\%) being the highest user of stock option grants. The industry spread is as follows:

14. A useful summary of the Australian debate on accounting for executive stock options may be found in the March, 2002 issue of the Australian Accounting Review.

15. The number of CEOs exceeds the number of companies due to CEO turnover. 


\begin{tabular}{|c|l|c|}
\hline 2-digit GICS & \multicolumn{1}{|c|}{ Description } & Percentage of grants \\
\hline 10 & Resources/Energy & 25.2 \\
15 & Materials & 12.9 \\
20 & Industrials & 21.3 \\
25 & Consumer Discretionary & 13.4 \\
30 & Consumer Staples & 16.8 \\
40 & Financials & 6.9 \\
55 & Utilities & 3.5 \\
\hline & Total & 100.0 \\
\hline
\end{tabular}

No distinction is made between first and subsequent grants to the same CEO. In other words, grants are treated as independent observations even if two or more grants are made in the same calendar year to the same CEO but at different exercise prices or maturities. Since both HM and $\mathrm{CH}$ posit incentive structures where the incentive level depends (partly) on absolute grant size and not grant size relative to outstanding capital, multiple grants differentiated by exercise prices or maturities are valid data points because each 'tranche' is independently exercised. Amalgamation of grants to the same CEO in the same fiscal year to obtain an 'average' exercise price would therefore obfuscate the analysis. ${ }^{16}$ In so doing, clustering is induced to the extent that to or more grants to the same CEO by the same firm in the same year will have common firm characteristics. However, this effect is addressed through specification of firm fixed effects in panel tests of the $\mathrm{CH}$ model. Clustering does not arise for tests of HM because multiple grants to the same CEO in the same year are in fact differentiated on exercise price, grant size or maturity. Given exercise price and grant size are simultaneously determined two techniques are employed to address the endogenity problem: namely, two-stage least squares (2SLS) with appropriate specification of instruments along with White-corrected standard errors. For example, for the former we test the determinants of exercise prices in a HM world the number of options granted is specified as an instrument along with risk aversion, private diversification and delta where the latter cannot be specified, while to test the determinants of grant sizes the exercise price is included as instrument.

16. Even so, we later obtain results when multiple grants are combined using weighted-average exercise prices. 


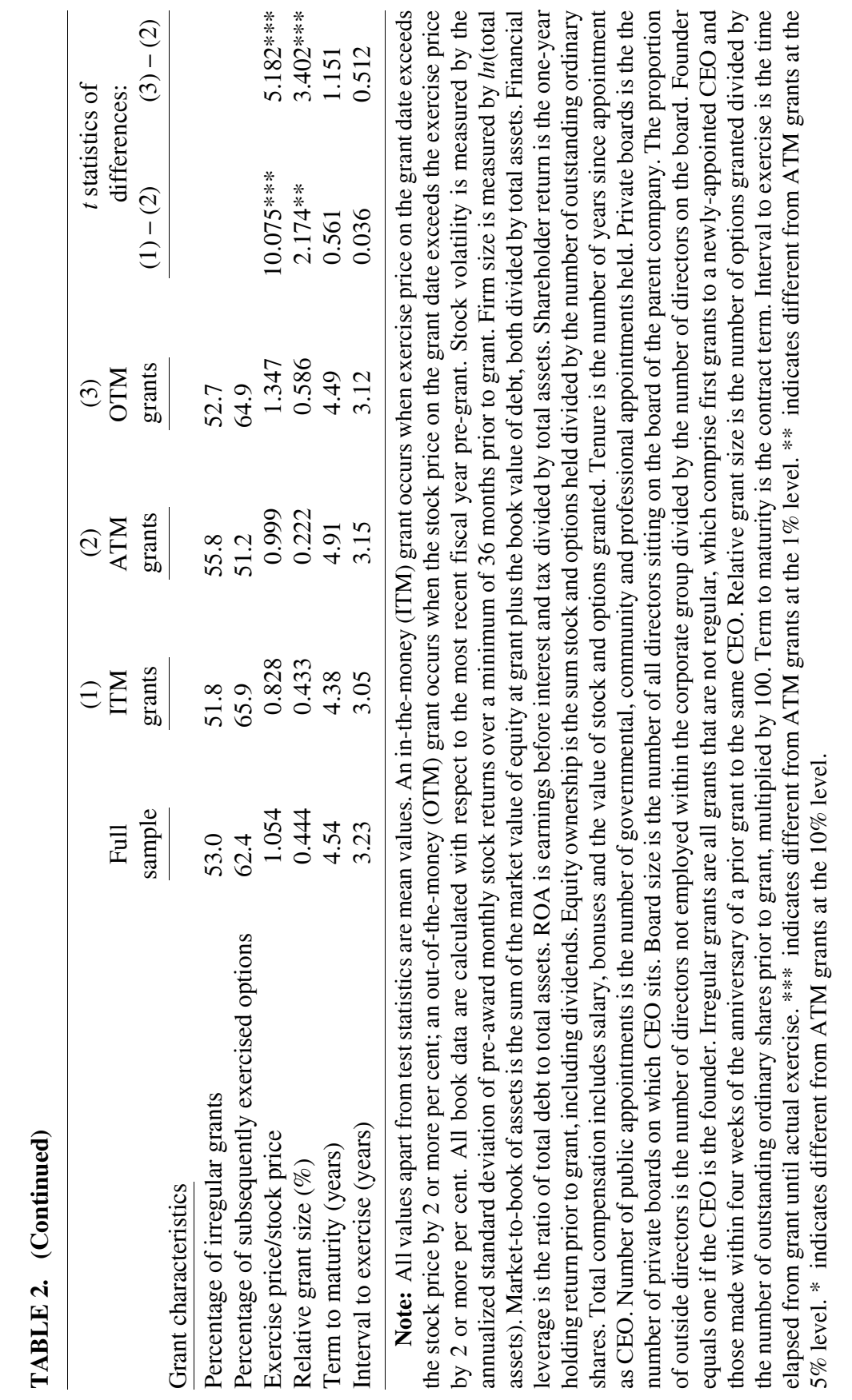




\section{Analysis}

Firm, governance and grant characteristics are described in table 2 by grant moneyness. The rule for identifying a grant as at-the-money yields $\frac{85}{202}$ ITM grants, $\frac{74}{202}$ OTM grants and $\frac{43}{202}$ ATM grants. For the full sample, all firm characteristics have more or less regular mean values apart from firm size reflecting the smaller size of Australian firms relative to their U.S. counterparts. Market-to-book of assets and financial leverage are somewhat below the values reported for U.S. firms in a comparable study by Cuny, Martin and Puthenpurackal (2009). Mean CEO equity ownership is (1.59 per cent) is lower than the 4.06 per cent reported by Kadan and Swinkels (2008) but nearly the same as reported by Baker and Hall (2004) (1.45 per cent). The mean percentage of salary to total compensation (32.08) is similar to that reported by Guay (1999). CEO age and tenure (49.27 and 4.17 years, respectively) are somewhat lower than comparable values for the U.S. (Coles, Daniel and Naveen (2006); Dittman and Maug (2007)). The number of public appointments is a reputation proxy. Mean board size is 7.56 persons and the proportion of outside or independent directors is 0.361 . The percentage of CEOs who are founders is 11.8 per cent. The percentage of irregular grants for the full sample (53.0 per cent) is similar across the moneyness categories. Nearly two-thirds of all grants (62.4 per cent) are subsequently exercised. The average granted option is slightly OTM, while the average grant equals 0.444 per cent of the number of outstanding common stock. The mean term to expiry is 4.54 years which about half the standard U.S. practice, while the mean interval to exercise is 3.23 years.

Relative to ATM grants, both ITM and OTM grants are shown in table 2 to be made by smaller firms with more volatile stock returns. Firms making ITM grants have CEOs with fewer public appointments and sitting on fewer private boards but have more CEOs who are founders than firms with ATM grants. On the other hand, relative to firms with ATM grants firms making OTM grants have smaller boards, a lower proportion of outside directors, their CEO is less likely to be a founder, has fewer public appointments and the firm is less complex, but the CEO has a higher proportion of salary in total compensation. Apart from board size, the differences in governance characteristics suggest that CEO influence is generally higher for non-ATM grants. For 
grant characteristics, the percentages of irregular grants are similar but a much smaller percentage of ATM grants are subsequently exercised in comparison with ITM and OTM grants. Exercise prices are right-skewed with premiums being proportionately higher than discounts. Relative grant sizes vary with moneyness for no apparent reason. Finally, term to expiry and interval to exercise show no evidence of variation with moneyness.

Table 3 describes the CEO incentive arguments for the full sample and by grant moneyness. The average CEO's inside wealth is $\$ 7.69$ million which is considerably smaller than that reported by Baker and Hall (2004) for U.S. firms (with founders deleted) but considerably larger than that implied by Becker (2006) for Swedish firms, both employing a similar sample period. Total wealth for Australian CEOs is likewise higher than for Swedish CEOs (Becker, 2006). The total compensation of Australian CEOs follows the same pattern. Private diversification is significantly higher for ATM grants relative to ITM grants (as predicted by HM) but contrary to HM is lower for OTM grants relative to ATM grants. Mean target risk (1.681) implies that the average option grant is designed to increase risk-taking by 68.1 per cent (assuming constant CEO productivity) and is significantly higher for ITM grants. The productivity of Australian CEOs (mean 7.4 per cent, median 2.4 per cent) compares with annualized growth in assets (mean 3.8 per cent, median 1.1 per cent) obtained from $(M B A)^{1 / L}-1$, where $M B A$ is market-to-book of assets at grant and $L$ is the mean economic life of assets proxied by gross Property, Plant and Equipment divided by Depreciation Expense. The fact that CEO productivity is about double that in the equity market's evaluation implies that this productivity is dissipated, providing circumstantial motivation for option grants. The option delta (mean 0.760 ) is slightly higher than the 0.7 commonly assumed (Hall and Murphy, 2002 and Becker, 2006) which is attributable to the presence of a disproportionate number of ITM grants in our data and also offsets the shorter maturity of Australian options. (Absolute) pay-performance sensitivity measured according to HM (mean 0.488) is somewhat lower than the relative $\mathrm{CH}$ measure (mean 0.649). With respect to grant moneyness, OTM grants are found associated with lower inside wealth, total wealth, total compensation and private diversification than ATM grants. ITM grants also are associated with lower private diversification than ATM grants. Only pay-performance sensitivity measured according to $\mathrm{CH}$ (PPS-CH) varies with moneyness, but only for OTM grants for which PPS-CH is higher 


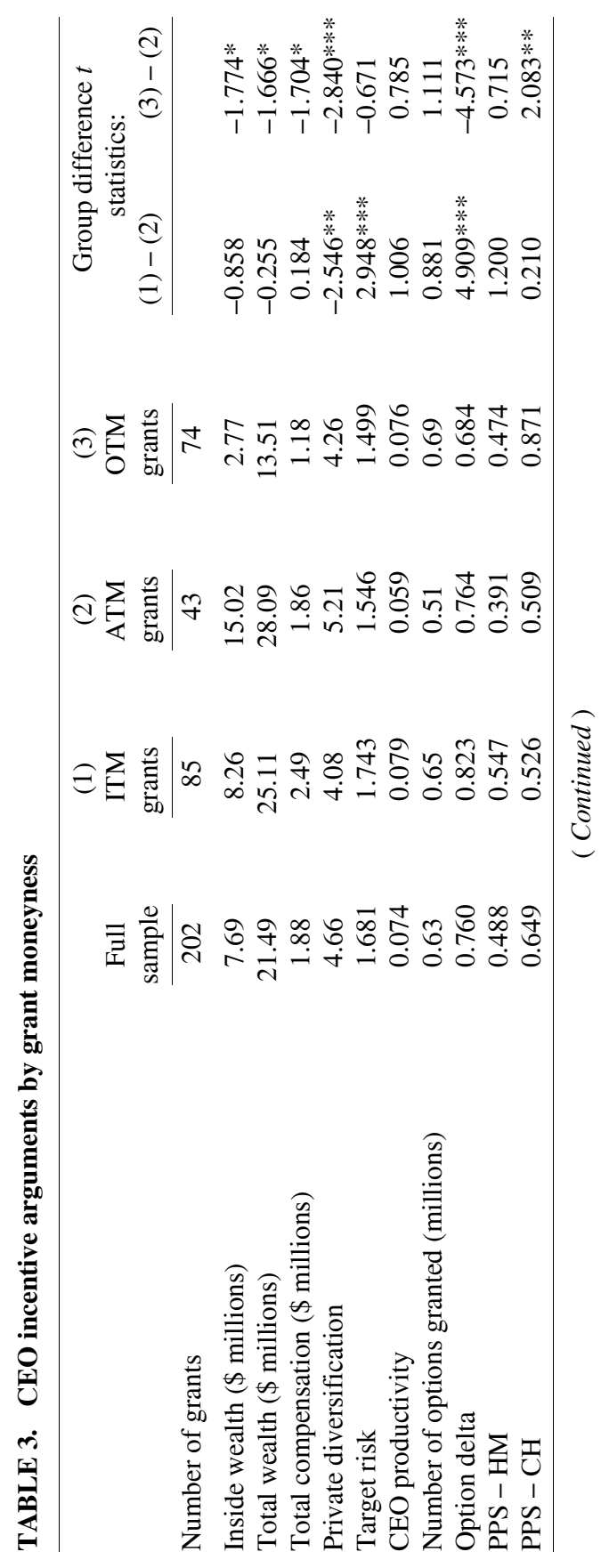




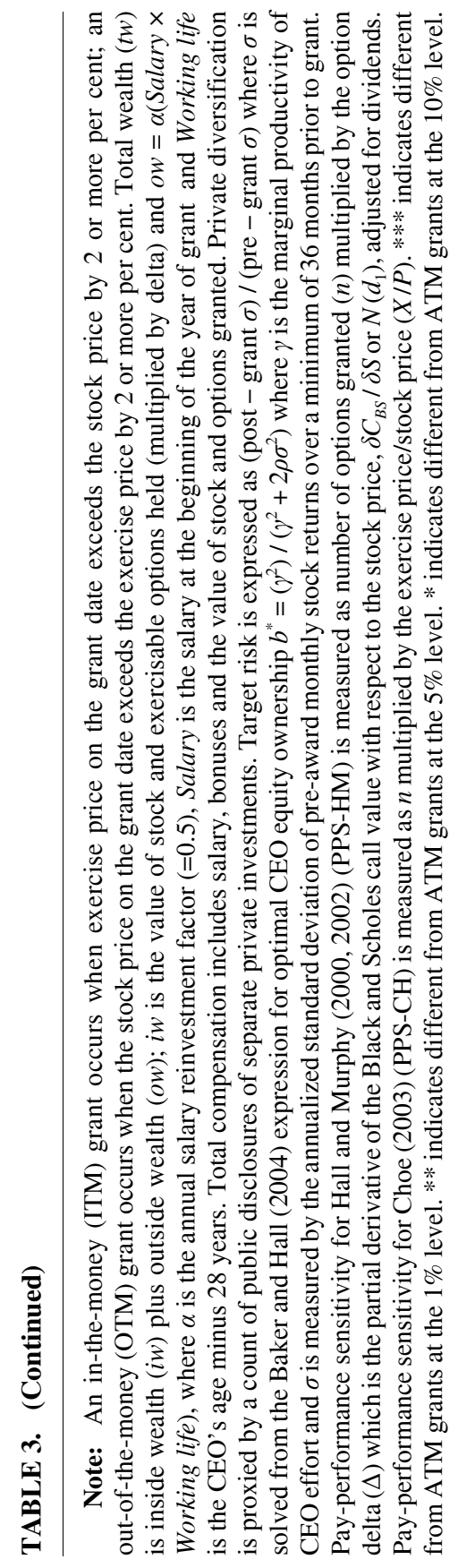


TABLE 4. Variable correlations

\begin{tabular}{|c|c|c|c|c|c|c|}
\hline$N=202$ & $\begin{array}{c}\text { Risk } \\
\text { aversion }\end{array}$ & $\begin{array}{c}\text { Private } \\
\text { diversification }\end{array}$ & $\begin{array}{l}\text { Inside } \\
\text { wealth }\end{array}$ & $\begin{array}{c}\text { Stock } \\
\text { volatility }\end{array}$ & $\begin{array}{l}\text { Firm } \\
\text { size }\end{array}$ & Tenure \\
\hline Risk aversion & 1 & & & & & \\
\hline $\begin{array}{l}\text { Private } \\
\text { diversification }\end{array}$ & $\begin{array}{l}-0.263 * * * \\
(-)\end{array}$ & 1 & & & & \\
\hline $\begin{array}{l}\text { Inside } \\
\text { wealth }\end{array}$ & $\begin{array}{l}0.274 * * * \\
(+)\end{array}$ & $\begin{array}{l}-0.104 * * \\
(-)\end{array}$ & 1 & & & \\
\hline $\begin{array}{l}\text { Stock } \\
\text { volatility }\end{array}$ & $\begin{array}{l}-0.505 * * * \\
(-)\end{array}$ & $\begin{array}{l}0.382 * * * \\
(+)\end{array}$ & -0.101 & 1 & & \\
\hline $\begin{array}{l}\text { Firm } \\
\text { size }\end{array}$ & $\begin{array}{l}0.653 * * * \\
(+)\end{array}$ & $\begin{array}{l}-0.445 * * * \\
(-)\end{array}$ & 0.077 & $-0.735^{* * *}$ & 1 & \\
\hline Tenure & $\begin{array}{l}0.159 * * \\
(+)\end{array}$ & $\begin{array}{l}0.004 \\
(-)\end{array}$ & $0.302 * * *$ & 0.053 & -0.110 & 1 \\
\hline
\end{tabular}

Note: Risk aversion in absolute terms $(\rho)$ is the natural log of outside wealth $(o w)$ where $o w=\alpha($ Salary $\times$ Working life $), \alpha$ is the annual salary reinvestment factor, Salary is the CEO's salary at the beginning of the grant year and Working life is the CEO's age minus 28 years. Private diversification is proxied by a count of public disclosures of separate private investments. Inside wealth is the value of stock and exercisable options held (multiplied by delta). Stock volatility is measured by the annualized standard deviation of pre-award monthly stock returns over a minimum of 36 months prior to grant. Firm size is measured by $\ln$ (total assets). Tenure is the number of years since appointment as CEO. Expected signs are shown in parentheses. $* * *$ indicates different from ATM grants at the $1 \%$ level. ** indicates different from ATM grants at the $5 \%$ level.

relative to ATM grants. Taken together, these regularities suggest that OTM grants in Australia are reserved for relatively poorer CEOs who are less diversified and who apparently require higher incentivization in relative terms.

The measure of (absolute) risk aversion is validated in table 4 which presents correlations between risk aversion and variables likely to impact on or be impacted by risk aversion, along with correlations among these variables. Risk aversion is expected (i) increasing in inside wealth because the CEO is exposed to a single (idiosyncratic) risk, (ii) decreasing in stock volatility because an undiversified CEO needs to be less risk averse to accept higher risk, (iii) increasing in firm size because larger firms tend to be more diversified, (iv) increasing in tenure because longer tenure suggests entrenchment and risk avoidance and (v) decreasing in private diversification. ${ }^{17}$ All risk aversion correlates are 
statistically significant and correctly signed. Overall, these results provide broad empirical support for our measure of risk aversion. The measure of private diversification is also validated in table 4 . Essentially, CEO private diversification is expected to have the opposite relation as risk aversion to the same variables because risk aversion and private diversification are inversely related. Apart from tenure (which is statistically insignificant) all other correlates are signed as expected.

Although tests of the two models are performed jointly in later tables, tests of the two models are first performed separately to determine their individual strength in explaining exercise prices and grant sizes. A direct test of $\mathrm{HM}$ is presented in table 5, while a direct test of $\mathrm{CH}$ is presented in table 6. Recall that HM posit exercise prices and grant sizes are jointly decreasing in both the option delta and risk aversion but increasing in private diversification. Panel 2SLS is employed to minimize simultaneous equation bias and endogeneity. Model (1) has Exercise price/stock price as the dependent variable controlling for Number of option grants while model (2) has Number of options granted as the dependent variable controlling for Exercise price/stock price. Results for the first-stage regression are reported first as (i) with results of the 2SLS (instrumental variables) regression reported second as (ii). For both models Risk aversion and Private diversification are specified as independent variables with firm characteristics specified as instruments. The option delta is generally excluded owing to very high correlation with Exercise price/stock price (as predicated by option pricing theory). The estimation of model (1) for $\mathrm{HM}$ is largely successful with Risk aversion and Private diversification both being correctly signed although Number of options granted fails to achieve positive significance. The complete failure of model (2) indicates that grant sizes are determined by factors outside the HM model and possibly exacerbated by noise from rounding which is prevalent in option grants:

\begin{tabular}{|r|r|l|l|}
\hline Range of grant sizes & $\begin{array}{l}\text { Number } \\
\text { of grants }\end{array}$ & $\begin{array}{l}\text { Grant size } \\
\text { ending in } \\
\text { (.) digits }\end{array}$ & $\begin{array}{l}\text { Percentage of } \\
\text { cases ending } \\
\text { in (.) digits }\end{array}$ \\
\hline $1-10,000$ & 8 & 00 & 100.0 \\
$10,000-100,000$ & 43 & 000 & 72.1 \\
$100,000-1,000,000$ & 116 & 0,000 & 82.8 \\
$1,000,000-10,000,000$ & 35 & 00,000 & 77.1 \\
\hline
\end{tabular}




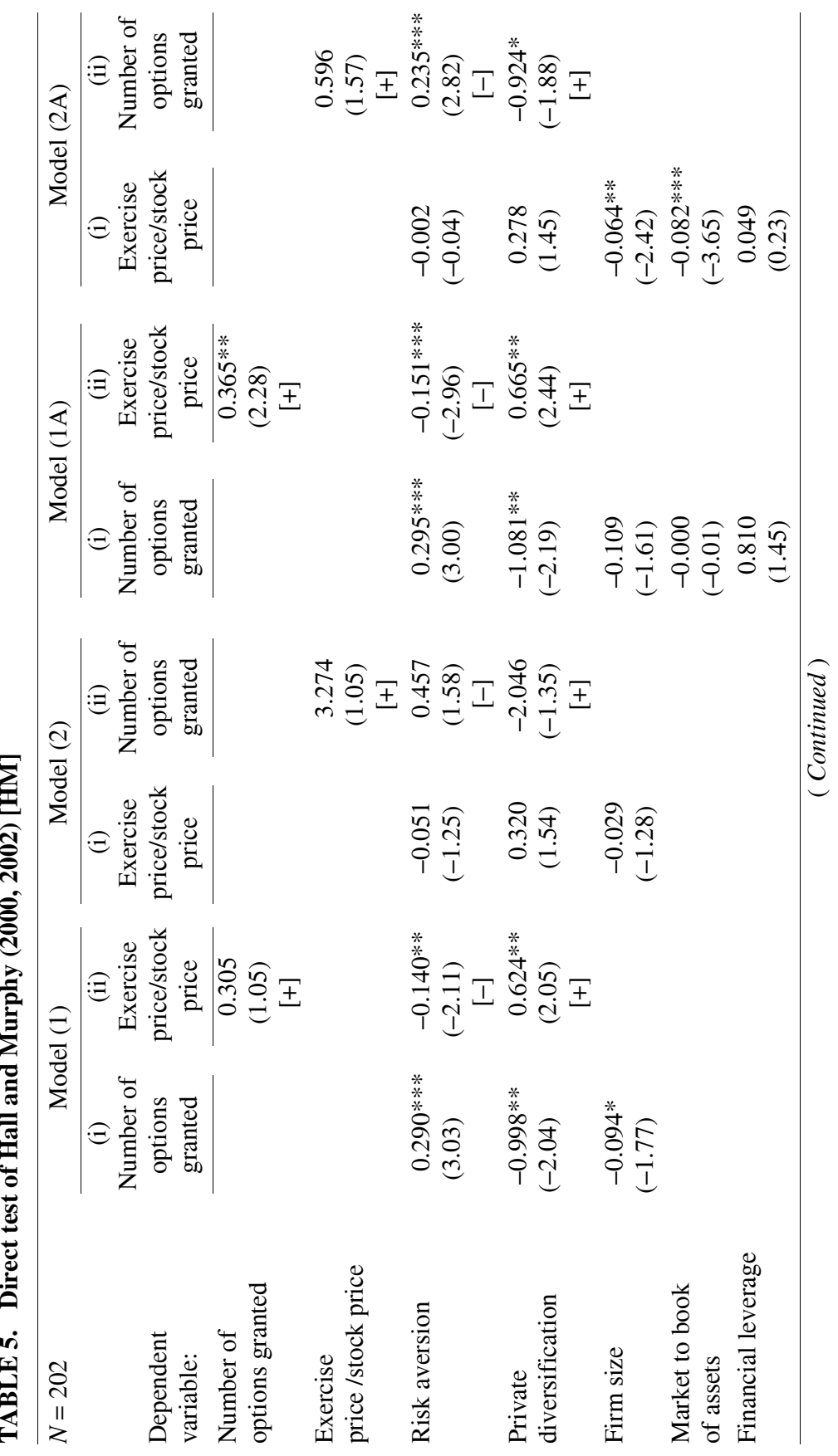




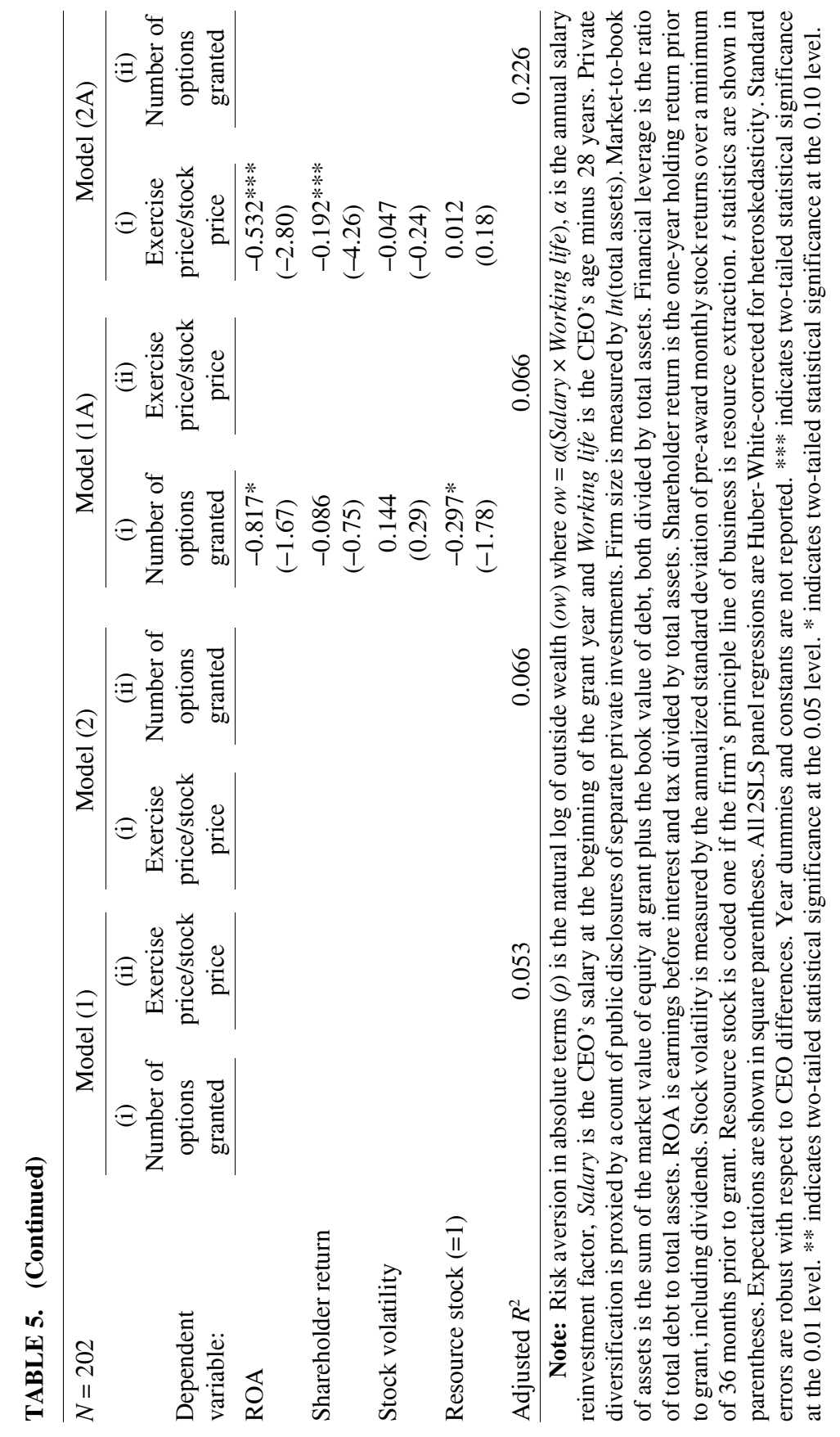




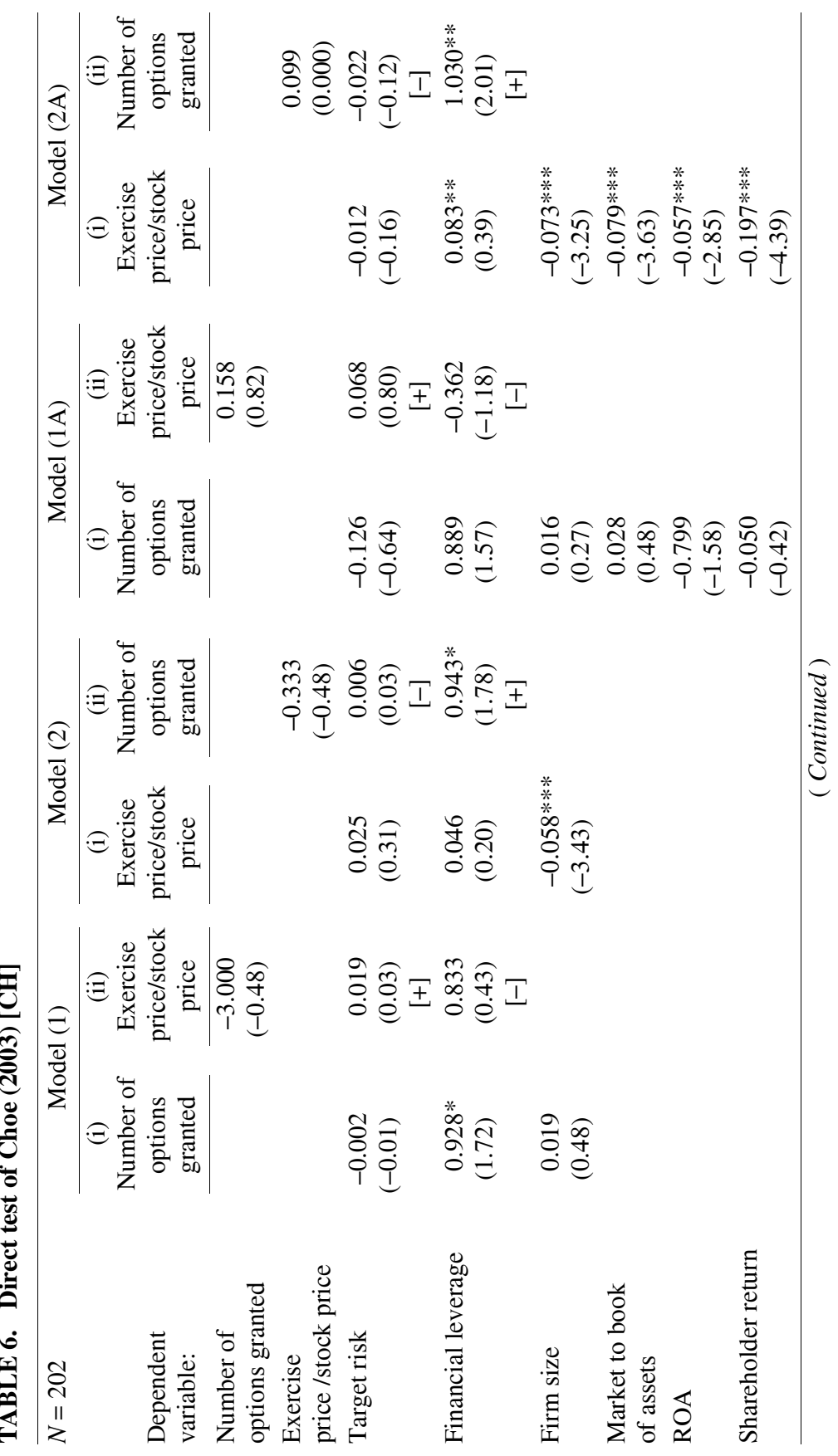




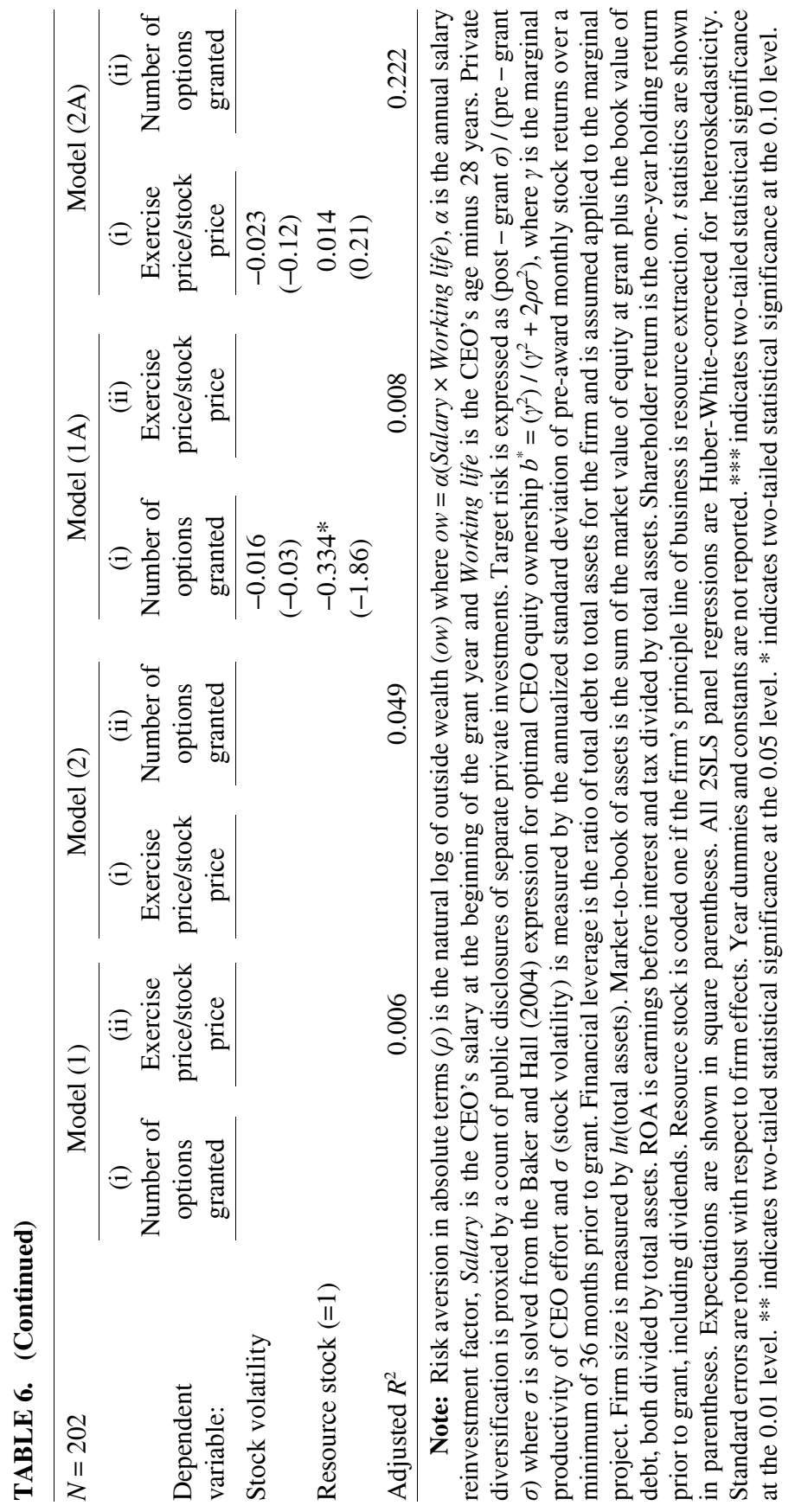


We next test whether the results of models (1) and (2) are robust with respect to inclusion of several instruments representing firm characteristics. Theoretically, the HM model should be immune to such factors. The estimations of models (1) and (2) are repeated with larger instrument sets and are reported as models (1A) and (2A), also in table 5. The fit of model (1A) is somewhat improved over that of model (1) but model (2A) fails. Thus, explaining grant size remains problematic.

The $\mathrm{CH}$ model is tested in table 6 with exercise prices specified as the dependent variable in model (1) and grant size in model (2), respectively. Compared with the $\mathrm{HM}$ estimations, the $\mathrm{CH}$ test fares worse with only Financial leverage in the 2SLS of model (2) being correctly signed. Adding further instruments to models (1A) and (2A) slightly improves the significance of leverage. Thus, financial leverage is the only firm characteristic found to have an association with grant size. $\mathrm{HM}$ and $\mathrm{CH}$ are jointly tested in table 7. The HM model is found to completely dominate $\mathrm{CH}$. Exercise prices continue to be determined by risk aversion and private diversification while financial leverage loses significance when included with risk aversion and private diversification. To this point, two main findings have emerged. First, grant sizes are not satisfactorily explained by either $\mathrm{HM}$ or $\mathrm{CH}$. Second, firm characteristics impact on exercise prices and lend support to financial leverage in explaining optimal grant size. Overall, optimal exercise prices are found to depend on CEO risk attitudes and not all on the host corporate environment.

We next explore whether governance factors impact directly on the arguments of $\mathrm{HM}$ and $\mathrm{CH}$. For example, influential and highly risk-averse CEOs of firms with weak corporate governance may demand larger grants than HM would predict, while less risk-averse CEOs may be satisfied with smaller grants. Likewise, CEOs facing steeper target risks will require higher incentivization if they are entrenched, while a founder as CEO might have the power to expropriate by accepting larger grants at a discount to market. To help resolve such issues the incremental explanatory power of governance variables are tested by substituting these as instruments for firm size. Table 8 presents the results of the panel 2SLS estimations which follow those of table 7 but with substitution of the governance variables. As before, model (1)(ii) is the key model for explaining exercise prices. The results are closely similar to model (1)(ii) of table 7 but with the added bonus that Number of options granted now achieves positive significance consistent with $\mathrm{HM}$ and which is attributed to the presence of the governance variables. 
TABLE 7. Joint tests of Hall and Murphy (2000, 2002) [HM] and Choe (2003) $[\mathrm{CH}]$

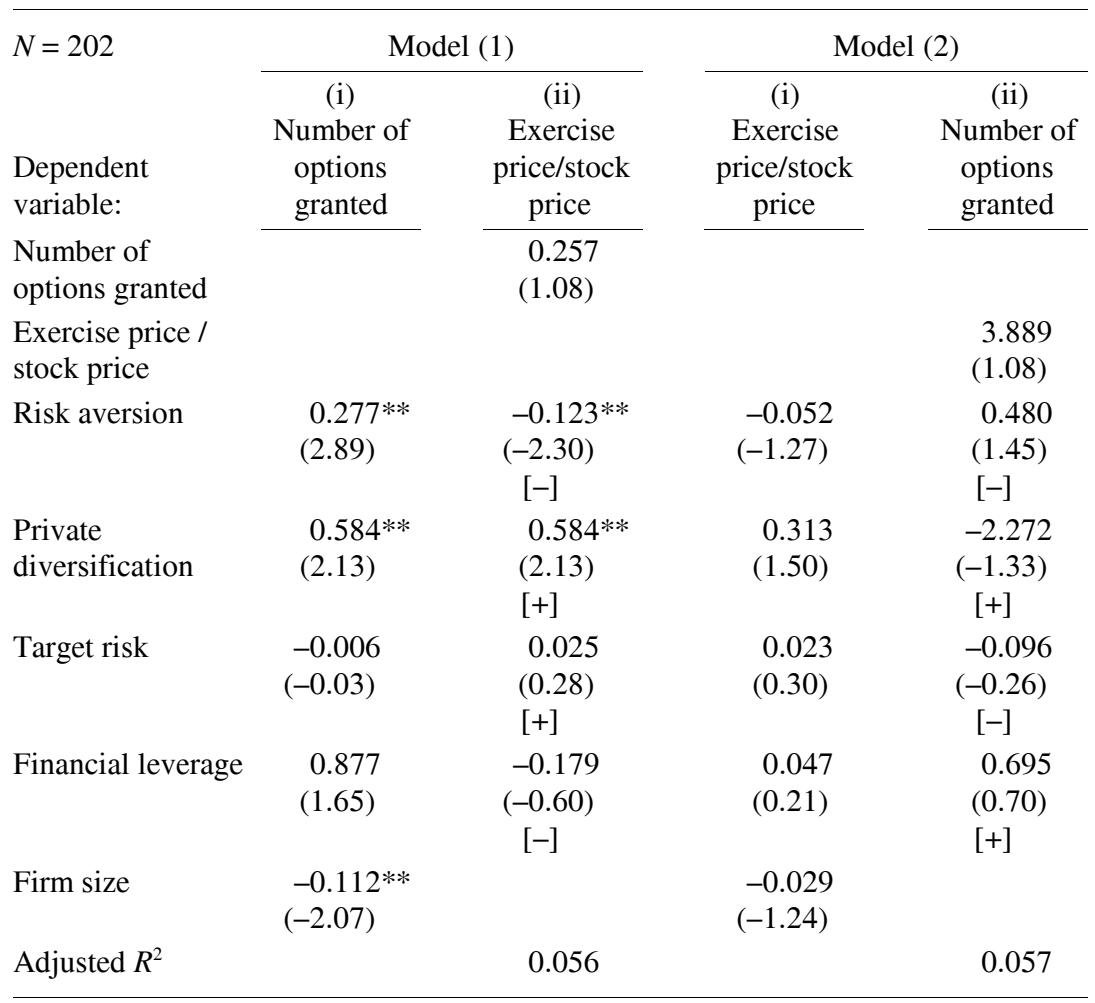

Note: Risk aversion in absolute terms $(\rho)$ is the natural log of outside wealth (ow) where $o w=\alpha($ Salary $\times$ Working life $), \alpha$ is the annual salary reinvestment factor, Salary is the CEO's salary at the beginning of the grant year and Working life is the CEO's age minus 28 years. Private diversification is proxied by a count of public disclosures of separate private investments. Target risk is expressed as (post - grant $\sigma$ ) / (pre - grant $\sigma$ ) where $\sigma$ is solved from the Baker and Hall (2004) expression for optimal CEO equity ownership $b^{*}=\left(\gamma^{2}\right) /\left(\gamma^{2}\right.$ $+2 \rho \sigma^{2}$ ), where $\gamma$ is the marginal productivity of CEO effort and $\sigma$ (stock volatility) is measured by the annualized standard deviation of pre-award monthly stock returns over a minimum of 36 months prior to grant. Financial leverage is the ratio of total debt to total assets for the firm and is assumed applied to the marginal project. $t$ statistics are shown in parentheses. Firm size is measured by $\ln$ (total assets). Expectations are shown in square parentheses. 2SLS panel regressions are Huber-White-corrected for heteroskedasticity. Standard errors are robust with respect to cross-sectional effects: CEO for HM and firm for $\mathrm{CH}$. Year dummies and constants are not reported. ** indicates two-tailed statistical significance at the 0.05 level.

Even so, three governance factors achieve statistical significance in first equation of model (1), namely, Board size (negative), Entrenchment 
TABLE 8. Joint tests of Hall \& Murphy (2000, 2002) [HM] and Choe (2003) [CH] with governance instruments

\begin{tabular}{|c|c|c|c|c|}
\hline \multirow[b]{2}{*}{$\begin{array}{l}\text { Dependent } \\
\text { variable: }\end{array}$} & \multicolumn{2}{|c|}{ Model (1) } & \multicolumn{2}{|c|}{ Model (2) } \\
\hline & $\begin{array}{c}\text { (i) } \\
\text { Number of } \\
\text { options } \\
\text { granted }\end{array}$ & $\begin{array}{c}\text { (ii) } \\
\text { Exercise } \\
\text { price/stock } \\
\text { price }\end{array}$ & $\begin{array}{c}\text { (i) } \\
\text { Exercise } \\
\text { price/stock } \\
\text { price }\end{array}$ & $\begin{array}{l}\text { (ii) } \\
\text { Number of } \\
\text { options } \\
\text { granted }\end{array}$ \\
\hline $\begin{array}{l}\text { Number of } \\
\text { options granted }\end{array}$ & & $\begin{array}{l}0.069^{*} \\
(1.76)\end{array}$ & & \\
\hline $\begin{array}{l}\text { Exercise price / } \\
\text { stock price }\end{array}$ & & & & $\begin{array}{l}2.165^{* *} \\
(2.38)\end{array}$ \\
\hline Risk aversion & $\begin{array}{l}0.353^{* * * *} \\
(2.79)\end{array}$ & $\begin{array}{c}-0.097 * * * \\
(-2.85) \\
{[-]}\end{array}$ & $\begin{array}{l}-0.100^{* * * *} \\
(-2.77)\end{array}$ & $\begin{array}{l}0.424 * * * \\
(2.75) \\
{[-]}\end{array}$ \\
\hline $\begin{array}{l}\text { Private } \\
\text { diversification }\end{array}$ & $\begin{array}{l}1.604 \\
(1.40)\end{array}$ & $\begin{array}{l}0.502 * * \\
(2.50) \\
{[+]}\end{array}$ & $\begin{array}{l}0.961^{* * * *} \\
(2.94)\end{array}$ & $\begin{array}{c}-2.186 * * \\
(-2.46) \\
{[+]}\end{array}$ \\
\hline Target risk & $\begin{array}{l}-0.658 * * \\
(-2.37)\end{array}$ & $\begin{array}{c}0.054 \\
(0.69) \\
{[+]}\end{array}$ & $\begin{array}{l}-0.020 \\
(-0.26)\end{array}$ & $\begin{array}{c}-0.339 \\
(-1.05) \\
{[-]}\end{array}$ \\
\hline Financial leverage & $\begin{array}{l}1.599 * * \\
(2.07)\end{array}$ & $\begin{array}{c}-0.124 \\
(-0.54) \\
{[-]}\end{array}$ & $\begin{array}{c}0.083 \\
(0.38)\end{array}$ & $\begin{array}{l}1.615 * \\
(1.75) \\
{[+]}\end{array}$ \\
\hline Board size & $\begin{array}{l}-0.267 * * \\
(-2.20)\end{array}$ & & $\begin{array}{l}0.057^{*} \\
(1.65)\end{array}$ & \\
\hline Outside directors & $\begin{array}{l}1.383 \\
(0.92)\end{array}$ & & $\begin{array}{l}-0.823 * \\
(-1.93)\end{array}$ & \\
\hline Tenure & $\begin{array}{r}0.051 \\
(1.18)\end{array}$ & & $\begin{array}{l}0.034 * * * \\
(2.91)\end{array}$ & \\
\hline Entrenchment $(=1)$ & $\begin{array}{l}-1.013 * * * \\
(-3.63)\end{array}$ & & $\begin{array}{l}-0.095 \\
(-1.20)\end{array}$ & \\
\hline Founder $(=1)$ & $\begin{array}{c}0.526 \\
(1.56)\end{array}$ & & $\begin{array}{l}-0.227 * * \\
(-2.37)\end{array}$ & \\
\hline $\begin{array}{l}\text { Public } \\
\text { appointments }\end{array}$ & $\begin{array}{c}-0.073 \\
(-1.24)\end{array}$ & & $\begin{array}{c}-0.016 \\
(-0.95)\end{array}$ & \\
\hline Private boards & $\begin{array}{l}0.407 * * * \\
(4.55)\end{array}$ & & $\begin{array}{l}0.072 * * * \\
(2.83)\end{array}$ & \\
\hline Adjusted & & 0.255 & & 0.123 \\
\hline
\end{tabular}

( Continued) 
TABLE 8. (Continued)

\begin{abstract}
Note: Risk aversion in absolute terms $(\rho)$ is the natural log of outside wealth $(o w)$ where $o w=\alpha($ Salary $\times$ Working life $) \alpha$ is the annual salary reinvestment factor, Salary is the CEO's salary at the beginning of the grant year and Working life is the CEO's age minus 28 years. Private diversification is proxied by a count of public disclosures of separate private investments. Target risk is expressed as (post - grant $\sigma$ ) / (pre - grant $\sigma$ ) where $\sigma$ is solved from the Baker and Hall (2004) expression for optimal CEO equity ownership $b^{*}=\left(\gamma^{2}\right) /\left(\gamma^{2}\right.$ $+2 \rho \sigma^{2}$ ) where $\gamma$ is the marginal productivity of CEO effort and $\sigma$ is measured by the annualized standard deviation of pre-award monthly stock returns over a minimum of 36 months prior to grant. Financial leverage is the ratio of total debt to total assets for the firm and is assumed applied to the marginal project. Board size is the number of all directors sitting on the board of the parent company. The proportion of outside directors is the number of directors not employed within the corporate group divided by the number of directors on the board. Tenure is the number of years since appointment as CEO. CEO entrenchment $(=1)$ when pre-grant equity ownership is between 5 and 25 per cent (Morck, Shleifer and Vishny, 1988). Founder equals 1 if CEO is the founder. Number of public appointments is the number of governmental, community and professional appointments held. Private boards is the number of private boards on which CEO sits. $t$ statistics are shown in parentheses. Expectations are shown in square parentheses. 2SLS panel regressions are Huber-White corrected for heteroskedasticity. Standard errors are robust with respect to cross-sectional effects: CEO for HM and firm for $\mathrm{CH}$. Year dummies and constants are not reported. *** indicates two-tailed statistical significance at the 0.01 level. **indicates two-tailed statistical significance at the 0.05 level. * indicates two-tailed statistical significance at the 0.10 level.
\end{abstract}

(negative) and Private boards (positive). All are signed in a manner consistent with 'benign' governance. For instance, given that large boards are more vulnerable to CEO influence smaller grants than optimal for large boards relative to small boards is expected to be observed. Again, higher private board membership which is indicative of competency implies that larger grants are in shareholders' interest.

Model (2)(ii) demonstrates qualified improvement over the fit reported in Model (2)(ii) of table 7. For the first time Exercise price/stock price is positively signed which is consistent with HM and consequent upon introduction of the governance variables. However, Risk aversion and Private diversification are now incorrectly signed, although Financial leverage is correctly signed. Four governance factors, Board size, Outside directors, Tenure and Entrenchment enter the first equation (Model (2((i)) adversely in that all suggest CEO influence; the lone exception is Private boards which enters benignly for shareholders. The reverse signage on Risk aversion and Private diversification suggests that grant sizes are increasing in exercise prices not as a consequence of the HM arguments but as a result of inclusion of governance variables in the first equation (Model (2)(i)). The four 
TABLE 9. Joint tests of Hall and Murphy (2000, 2002) [HM] and Choe (2003) $[\mathrm{CH}]$ without at-the-money grants

\begin{tabular}{|c|c|c|c|c|}
\hline$N=159$ & & & Mod & \\
\hline $\begin{array}{l}\text { Dependent } \\
\text { variable: }\end{array}$ & $\begin{array}{c}\text { (i) } \\
\text { Number of } \\
\text { options } \\
\text { granted }\end{array}$ & $\begin{array}{c}\text { (ii) } \\
\text { Exercise } \\
\text { price/stock } \\
\text { price }\end{array}$ & $\begin{array}{c}\text { (i) } \\
\text { Exercise } \\
\text { price/stock } \\
\text { price }\end{array}$ & $\begin{array}{c}\text { (ii) } \\
\text { Number of } \\
\text { options } \\
\text { granted }\end{array}$ \\
\hline $\begin{array}{l}\text { Number of } \\
\text { options granted }\end{array}$ & & $\begin{array}{c}0.281 \\
(0.91) \\
{[+]}\end{array}$ & & \\
\hline $\begin{array}{l}\text { Exercise price / } \\
\text { stock price }\end{array}$ & & & & $\begin{array}{c}3.827 \\
(0.91) \\
{[+]}\end{array}$ \\
\hline Risk aversion & $\begin{array}{l}0.262 * * \\
(2.31)\end{array}$ & $\begin{array}{c}-0.143^{* *} \\
(-2.31) \\
{[-]}\end{array}$ & $\begin{array}{l}-0.074 \\
(-1.46)\end{array}$ & $\begin{array}{c}0.546 \\
(1.15) \\
{[-]}\end{array}$ \\
\hline $\begin{array}{l}\text { Private } \\
\text { diversification }\end{array}$ & $\begin{array}{l}-1.214 * * \\
(-2.19)\end{array}$ & $\begin{array}{c}0.665^{*} \\
(1.86) \\
{[+]}\end{array}$ & $\begin{array}{r}0.347 \\
(1.41)\end{array}$ & $\begin{array}{c}-2.544 \\
(-1.21) \\
{[+]}\end{array}$ \\
\hline Target risk & $\begin{array}{c}0.031 \\
(0.14)\end{array}$ & $\begin{array}{c}0.026 \\
(0.23)\end{array}$ & $\begin{array}{c}0.034 \\
(0.35)\end{array}$ & $\begin{array}{c}-0.100 \\
(-0.21) \\
{[-]}\end{array}$ \\
\hline Financial leverage & $\begin{array}{c}0.891 \\
(1.39)\end{array}$ & $\begin{array}{l}-0.137 \\
(-0.36)\end{array}$ & $\begin{array}{c}0.095 \\
(0.33)\end{array}$ & $\begin{array}{c}0.527 \\
(0.42) \\
{[+]}\end{array}$ \\
\hline Firm size & $\begin{array}{l}-0.111 * \\
(-1.77)\end{array}$ & & $\begin{array}{l}-0.029 \\
(-1.03)\end{array}$ & \\
\hline Intercept & $\begin{array}{l}1.241 * \\
(1.95)\end{array}$ & $\begin{array}{l}0.785^{* *} \\
(2.49)\end{array}$ & $\begin{array}{l}1.110 * * * \\
(3.90)\end{array}$ & $\begin{array}{l}-2.859 \\
(-0.67)\end{array}$ \\
\hline Adjusted & & 0.048 & & 0.064 \\
\hline
\end{tabular}

Note: Risk aversion in absolute terms is the natural log of outside wealth (ow) where $o w$ $=\alpha$ (Salary $\times$ Working life $) \alpha$ is the annual salary reinvestment factor, Salary is the CEO's salary at the beginning of the grant year and Working life is the CEO's age minus 28 years. Private diversification is proxied by a count of public disclosures of separate private investments. Target risk is expressed as (post - grant $\sigma$ ) / (pre - grant $\sigma$ ) where $\sigma$ is solved from the Baker and Hall (2004) expression for optimal CEO equity ownership $b^{*}=\left(\gamma^{2}\right) /\left(\gamma^{2}\right.$ $+2 \rho \sigma^{2}$ ), where $\gamma$ is the marginal productivity of CEO effort and $\sigma$ (stock volatility) is measured by the annualized standard deviation of pre-award monthly stock returns over a minimum of 36 months prior to grant. Financial leverage is the ratio of total debt to total assets for the firm and is assumed applied to the marginal project. Firm size is measured by $\ln$ (total assets). $t$ statistics are shown in parentheses. Expectations are shown in square parentheses. All 2SLS panel regressions are Huber-White-corrected for heteroskedasticity. Standard errors are robust with respect to CEO differences. Year dummies are not reported. *** indicates two-tailed statistical significance at the 0.01 level. $* *$ indicates two-tailed statistical significance at the 0.05 level. * indicates two-tailed statistical significance at the 0.10 level. 
governance variables (identified above) are differently signed from Model (1)(i). Specifically, when CEOs exert influence it appears that large grants are driven not by lower risk aversion and higher private diversification (in accord with $\mathrm{HM}$ ). Neither are they driven by the $\mathrm{CH}$ arguments because the bare significance on Financial leverage is not paired with a negative sign on Exercise price/stock price (which is positively signed). We conclude that CEO influence is pivotal in explaining grant sizes but not exercise prices.

The final task is to demonstrate the robustness of our results. The results are apparently robust to aggregation of grants within the same fiscal year to the same CEO and not necessarily having the same exercise price/stock price relation. As it stands, any multiple grants are aggregated resulting in an average exercise price weighted by the individual grant sizes yielding 'average' convexities. Elimination of multiple grants leaves us with a reduced sample of 171 grants on which the models of tables 5 and 6 are then re-estimated but the results are generally inferior so are not reproduced here. A further robustness check is performed by excluding the 43 ATM grants which might be subject to company rules rather than unconstrained company decisions. ${ }^{18}$ The vehicle is the table 7 structure which is re-estimated with the ATM grants deleted. The results, which are reported in table 9, show the findings are robust to the possibility that ATM grants are differently motivated.

\section{Conclusions}

In $\mathrm{HM}$ the levels of executive risk aversion and private diversification determine pay-performance sensitivity which is the product of absolute grant size and the option delta. Essentially, increasing absolute risk aversion (coupled with declining private diversification) requires smaller ITM grants. Their arguments are independent of the characteristics of the host firm. In a complementary model, $\mathrm{CH}$ develops a set of arguments linking optimal incentive creation with firm characteristics. For a given exercise price, grant size is predicted to increase as option value (implied by lower stock volatility) decreases while for a given grant size the exercise price is predicted decreasing in leverage. Neither model has been tested empirically. The potential

18. We thank an anonymous referee for raising this point. 
interaction of corporate governance arguments with the $\mathrm{HM}$ and $\mathrm{CH}$ models has similarly not been tested.

We report the first tests of the key incentive-related propositions contained in the models of $\mathrm{HM}$ and $\mathrm{CH}$. Use of Australian data is justified on the dual grounds of freely-adjusting exercise prices and grant sizes along with a sample period 1987-2000 that in Australia predates executive stock option expensing requirements. For testing HM we note that the proxy for absolute risk aversion possesses desirable properties. The measure of private diversification is constructed from hand-collected disclosures. There are two main findings. First, the HM model satisfactorily explains exercise prices with reference to risk aversion and private diversification. However, and second, grant size remains essentially unexplained by either model. Financial leverage in the $\mathrm{CH}$ model barely explains grant sizes and is robust with respect to firm characteristics but not governance variables. CEO influence impacts on grant sizes adversely in the sense that grant sizes are larger than posited by the optimal incentive; at the same time, CEO influence does not impact on exercise prices. Finally, the results are robust with respect to exclusion of ATM grants.

Accepted by: Prof. P. Theodossiou, Editor-in-Chief, November 2012

\section{References}

Aggarwal, R. K., and Samwick, A. A. 1999. The Other Side of the Tradeoff: The Impact of Risk on Executive Compensation. Journal of Political Economy 107: 65-105.

Australian Accounting Standards Board, AASB 2, "Share-based Payment", Melbourne, Australia, 2004.

Baker, G., and Hall, B. 2004. CEO Incentives and Firm Size. Journal of Labor Economics 22: 767-798.

Baranchuk, N. 2006. Are CEOs Charged for Stock-Based Pay? An Instrumental Variable Analysis, Working paper, School of Management, University of Texas-Dallas (March).

Bebchuk, L., and Fried, J. 2003. Executive Compensation as an Agency Problem. Journal of Economic Perspectives 17: 71-92.

Bebchuk, L.; Grinstein, Y.; and Peyer, U. 2010. Lucky CEOs and Lucky Directors. Journal of Finance 65: 2363-2401.

Becker, Bo. 2006. Wealth and Executive Compensation. Journal of Finance 61: 379-397.

Bertrand, M., and Mullainathan, S. 2000. Agents With and Without Principals. 
American Economic Review 90: 203-208

Carpenter, J. N. 2000. Does Option Compensation Increase Managerial Risk Appetite? Journal of Finance 55: 2311-2331.

Choe, C. 2003. Leverage, volatility and executive stock options. Journal of Corporate Finance 9: 591-609.

Coles, J.; Daniel, N.; and Naveen, L. 2006. Managerial incentives and risk-taking. Journal of Financial Economics 79: 431-468.

Collins, D.W.; Gong, G.; and Li, H. 2005. The Timing of CEO Stock Option Grants: Scheduled versus Unscheduled Awards, Working paper, University of Iowa, Department of Accounting.

Conyon, M. J., and Sadler, G. 2001. CEO Compensation, Option Incentives and Information Disclosure. Review of Financial Economics 10: 251-277.

Core, J. E., and Guay, W. R. 2005. Is U.S. Compensation Broken? Journal of Applied Corporate Finance 17: 97-104.

Cuny, C. J.; Martin, G. S.; and Puthenpurackal, J. J. 2009. Stock Options and Total Payout. Journal of Financial and Quantitative Analysis 44: 391 410.

Dittmann, I., and Maug, E. 2007. Lower Salaries and no Options? On the Optimal Structure of Executive Pay. Journal of Finance 62: 303-343.

Dittmann, I., and Yu, K. 2010. How Important are Risk-Taking Incentives in Executive Compensation? Working paper, Erasmus University, Rotterdam, December 11.

Guay, W. R. 1999. The sensitivity of CEO wealth to equity risk: an analysis of the magnitude and determinants. Journal of Financial Economics 53:43-71.

Hall, B. J. 1999. The Design of Multi-Year Stock Option Plans. Journal of Applied Corporate Finance 12: 97-106.

Hall, B. J., and Liebman, J. B. 1998. Are CEOs Really Paid Like Bureaucrats? The Quarterly Journal of Economics 63: 653-691.

Hall, B. J., and Murphy, K. J. 2000. Optimal Exercise Prices for Executive Stock Options, The American Economic Review, Papers and Proceedings of the $112^{\text {th }}$ Annual Meeting of the American Economic Association, May: 209-214.

Hall, B. J., and Murphy, K. J. 2002. Stock options for undiversified executives. Journal of Accounting and Economics 33: 3-42.

Jensen, Michael C., and William H. Meckling, 1976, Theory of the Firm: Managerial Behavior, Agency Costs, and Ownership Structure, Journal of Financial Economics 3, 305-360.

Jensen, M. C., and Murphy, K. J. 1990. Performance Pay and Top-Management Incentives. Journal of Political Economy 98: 225-264.

Jian, M., and Lee, K. W. 2011. Does CEO reputation matter for capital investments? Journal of Corporate Finance 17: 929-946.

Kadan, O., and Swinkels, J. 2008. Stocks or Options? Moral Hazard, Firm Viability and the Design of Compensation Contracts. Review of Financial Studies 21: 451-482. 
Meulborek, L. 2001. The efficiency of equity-linked compensation: Understanding the full cost of awarding executive stock options. Financial Management 30: 5-44.

Morck, R.; Shleifer, A.; and Vishny, R. W. 1988. Management ownership and market valuation: an empirical analysis. Journal of Financial Economics 20: 293-315.

Narayanan, M.P., and Seyhun, H. N. 2006. Dating Games: Do Managers Designate Grant Dates to Increase their Compensation? Working paper, University of Michigan (April).

Rosser, B. A., and Canil, J. M. 2004, Executive Stock Options: Evidence that Premium and Discount Awards Do Matter, Working paper, University of Adelaide, Australia (July).

Taylor, S. J., and Coulton, J. 2002. Options Awards for Australian CEOs: The Who, What and Why. Australian Accounting Review 12: 25-35.

Weisbach, M. S. 1988. Outside directors and CEO turnover. Journal of Financial Economics 20: 431-460.

Yermack, D. 1995. Do corporations award CEO stock options effectively? Journal of Financial Economics 39: 237-269. 